Tropical Journal of Pharmaceutical Research, June 2007; 6 (2): 687-693

(c) Pharmacotherapy Group, Faculty of Pharmacy, University of Benin

Benin City, Nigeria.

All rights reserved.

Research Article

Available online at http://www.tjpr.org

\title{
Design and Development of a Proniosomal Transdermal Drug Delivery System for Captopril
}

\author{
Ankur Gupta*, Sunil Kumar Prajapati, M Balamurugan, Mamta \\ Singh, Daksh Bhatia \\ College of Pharmacy, ISI-15, Sitapura Institutional Area, Tonk Road,Jaipur-302022, Rajasthan
}

\begin{abstract}
Purpose: The aim of the study was to develop a proniosomal carrier system for captopril for the treatment of hypertension that is capable of efficiently delivering entrapped drug over an extended period of time.

Method: The potential of proniosomes as a transdermal drug delivery system for captopril was investigated by encapsulating the drug in various formulations of proniosomal gel composed of various ratios of sorbitan fatty acid esters, cholesterol, lecithin prepared by coacervation-phase separation method. The formulated systems were characterized in vitro for size, vesicle count, drug entrapment, drug release profiles and vesicular stability at different storage conditions. Stability studies for proniosomal gel were carried out for 4 weeks.

Results: The method of proniosome loading resulted in an encapsulation yield of $66.7-78.7 \%$. Proniosomes were characterised by transmission electron microscopy. In vitro studies showed prolonged release of entrapped captopril. At refrigerated conditions, higher drug retention was observed.

Conclusion: It is evident from this study that proniosomes are a promising prolonged delivery system for captopril and have reasonably good stability characteristics.
\end{abstract}

KEYWORDS: Proniosomes, Captopril, In vitro release, Transdermal delivery, Stability studies.

*Correspondence: Tel: +91-9828587508 E-mail: bupharma@gmail.com 


\section{INTRODUCTION}

To pursue optimal drug action, functional molecules could be transported by a carrier to the site of action and released to perform their task ${ }^{1}$. Non-ionic surfactant vesicles known as niosomes are microscopic lamellar structures formed on admixture of a non-ionic surfactant, cholesterol and dicetyl phosphate with subsequent hydration in aqueous media ${ }^{2}$. Proniosomes offer a versatile vesicle drug delivery concept with potential for delivery of drugs via transdermal route. This would be possible if proniosomes form niosomes upon hydration with water from skin following topical application under occlusive conditions ${ }^{3}$. Proniosomes minimizes problems of niosomes physical stability such as aggregation, fusion and leaking and provide additional convenience in transportation, storage and dosing ${ }^{4}$. Transdermal therapeutic system has generated an interest as this system provides the considerable advantage of a non-invasive parentral route for drug therapy, avoidance of first pass gut and hepatic metabolism, decreased side effects and relative ease of drug input termination in problematic cases 5 . Captopril, an orally active inhibitor of an angiotensin-converting enzyme (ACE) has been widely used for the treatment of hypertension and congestive heart failure. The drug is considered a drug of choice in antihypertensive therapy due to its effectiveness and low toxicity 6 . Captopril shows $75 \%$ bioavailability but presence of food reduces the oral absorption by $30-50 \%$. According to a previous research, the oxidation rate of captopril in dermal homogenate is significantly lower than the intestinal homogenate because the oxidative product of captopril, a captopril disulfide shows poor absorption from the intestine 7 . Captopril when administered initially causes hypotension, which can prove to be harmful in diuretic treated- and congestive heart failure patients. Persistent hypotension may cause some trouble in myocardial infraction patients ${ }^{8}$. Therefore, the use of transdermal drug delivery system, can reduce the side effects associated with captopril. Niosome carriers, well known for their potential in topical drug delivery, have been used to transport captopril molecule in the skin layer.

The objective of this study was to determine the factors influencing the encapsulation of captopril in proniosomal gel and to optimize encapsulation parameters in order to achieve a suitable delivery system.

\section{EXPERIMENTAL}

\section{Materials}

Captopril was a gift from Promed (Delhi, India). Soya lecithin, cholesterol, and dialysis tubing were purchased from Hi-Media Laboratories (Mumbai, India). Span 20, 40, 60, 80 and sorbitol were purchased from Central Drug House (Mumbai, India).

Development of Proniosomal Gel

Proniosomal gel was prepared by a coacervation-phase separation method 9 . Precisely weighed amounts of surfactant, lecithin, cholesterol and drug were taken in a clean and dry wide mouthed glass vial of $5.0 \mathrm{ml}$ capacity and alcohol $(0.5 \mathrm{ml})$ was added to it. After warming, all the ingredients were mixed well with a glass rod; the open end of the glass bottle was covered with a lid to prevent the loss of solvent from it and warmed over water bath at $60-70^{\circ} \mathrm{C}$ for about $5 \mathrm{~min}$ until the surfactant mixture was dissolved completely. Then the aqueous phase $(0.1 \%$ glycerol solution $)$ was added and warmed on a water bath till a clear solution was formed which was converted into proniosomal gel on cooling. The gel so obtained was preserved in the same glass bottle in dark conditions for characterization. Compositions of proniosomal gel formulations are given in Table 1.

\section{Characterization of Proniosomal Gel}

Vesicle Size Analysis: Hydration of proniosomal gel $(100 \mathrm{mg})$ was done by adding saline solution $(0.9 \%$ solution $)$ in a small glass vial with occasional shaking for $10 \mathrm{~min}$. The dispersion was observed under optical microscope (Olympus, New Delhi) at $100 \times$ magnification. The sizes of 200-300 vesicles were measured using a calibrated ocular and stage micrometer (Erma, Tokyo) fitted in the optical microscope ${ }^{9}$. 
Rate of Spontaneity: Approximately 10 or 20 $\mathrm{mg}$ of proniosomal gel was transferred to the bottom of a clean stoppered glass bottle and spread uniformly around the wall of the glass bottle with the help of a glass rod. At room temperature, $2 \mathrm{ml}$ of phosphate saline $(0.154 \mathrm{M}$ $\mathrm{NaCl}$ ) was added carefully along the walls of the glass bottle and left in a test-tube stand ${ }^{9}$. After 20 minutes, a drop of this saline solution was withdrawn and placed on Neubauers Chamber (Marienfeld, Germany) to count the number of vesicles. The number of niosomes eluted from proniosomes were counted.

Encapsulation Efficiency: To evaluate the loading capacity of proniosomal systems for captopril, proniosomal gel $(100 \mathrm{mg})$ was dispersed in distilled water and warmed a little for the formation of niosomes. Then the dispersion was centrifuged at $18000 \mathrm{rpm}$ for 40 $\min$ at $5^{\circ} \mathrm{C}$ (Remi CPR-24 centrifuge) ${ }^{10}$. The clear fraction was used for the determination of free drug at $212 \mathrm{~nm}$ spectrophotometrically. The percentage encapsulation efficiency was calculated from Equation 1.

\% Encapsulation Efficiency=[1- (Unencapsulated drug / Total drug)] x $100 \ldots$...(1)

In Vitro Release: In vitro release studies on proniosomal gel were performed using locally manufactured Franz-diffusion cell. The capacity of receptor compartment was $15 \mathrm{ml}$. The area of donor compartment exposed to receptor compartment was $1.41 \mathrm{~cm}^{2}$. The dialysis cellophane membrane (MMC014KDC) was mounted between the donor and receptor compartment. A weighed amount of proniosomal gel was placed on one side of the dialysis membrane. The receptor medium was phosphate saline buffer $\mathrm{pH}$ 7.4. The receptor compartment was surrounded by a water jacket to maintain the temperature at $37 \pm 1^{\circ} \mathrm{C}$. Heat was provided using a thermostatic hot plate with a magnetic stirrer. The receptor fluid was stirred by a Teflon-coated magnetic bead fitted to a magnetic stirrer (Bio-Craft Scientific Systems Pvt. Ltd., Agra) ${ }^{9}$.

At each sampling interval, samples were withdrawn and were replaced by equal volumes of fresh receptor fluid on each occasion. Samples withdrawn were analyzed spectrophotometrically (Shimadzu-1700) at 212 $\mathrm{nm}$.

Stability Studies: The ability of vesicles to retain the drug (Drug Retention Behaviour) was assessed by keeping the proniosomal gel at three different temperature conditions, i.e., Refrigeration Temperature $\left(4-8^{\circ} \mathrm{C}\right)$, Room Temperature $\left(25 \pm 2^{\circ} \mathrm{C}\right)$ and oven $\left(45 \pm 2^{\circ} \mathrm{C}\right)$. Throughout the study, proniosomal formulations were stored in aluminium foil-sealed glass vials. The samples were withdrawn at different time intervals over a period of one month and drug leakage from the formulations was analyzed for drug content spectrophotometrically ${ }^{11}$.

\section{RESULTS AND DISCUSSION}

Several novel carrier systems suggested as appropriate for captopril delivery include beadlets 12 , microcapsules 13 bioadhesive system 14, floating tablets and capsules 15, semisolid matrix systems ${ }^{16}$, and microspheres ${ }^{17}$. Proniosomes have generated interest as a topical formulation as an approach to avoid the side effects associated with oral administration. To achieve the desirable therapeutic effect of proniosomes as drug carriers, they must be loaded with sufficient amount of active compound. Table 2 shows the effect of various sorbitan fatty acid esters and their ratio on the encapsulation of captopril in proniosomal gel. Captopril was best encapsulated by proniosomal prepared using Spans 40 and 60. This might be attributed to fact that Spans 40 and 60 are solid at room temperature and showed a higher phase transition temperatures [Tc] ${ }^{18}$. The entrapment efficiency of Span 80 formulations was $11 \%$ less than those of Span 60. Spans 60 and 80 have the same head group, but Span 80 has an unsaturated alkyl chain. Introduction of a double bond into the paraffin chain causes a marked enhancement in the permeability in liposomes. This might be the reason for the lower entrapment efficiency of the Span 80 system ${ }^{19}$. Determination of vesicle size is important for the topical application of vesicles. Size was reduced when the dispersion was agitated. The reason for this is the energy applied in the agitation which results in the breakage of the larger vesicles to smaller vesicles. The size range was 
Gupta et al

Table 1: Composition of Proniosomal Gel Formulation

\begin{tabular}{|c|c|c|c|c|c|c|c|c|}
\hline S. No. & $\begin{array}{c}\text { Formulation } \\
\text { Code }\end{array}$ & $\begin{array}{c}\text { Surfactant } \\
\text { Type }\end{array}$ & $\begin{array}{l}\text { Ratio* } \\
\text { (mg) }\end{array}$ & $\begin{array}{l}\text { Lecithin } \\
\text { (mg) }\end{array}$ & $\begin{array}{c}\text { Cholesterol } \\
\text { (mg) }\end{array}$ & $\begin{array}{c}\text { Alcohol } \\
(\mathrm{ml})\end{array}$ & $\begin{array}{c}\text { Water } \\
(\mathrm{ml})\end{array}$ & Observation \\
\hline 1 & AGL1 & S20:S40 & $100: 900$ & 100 & 100 & 0.5 & 0.18 & White Semi-solid \\
\hline 2 & AGL2 & S20:S40 & $500: 500$ & 100 & 100 & 0.5 & 0.18 & $\begin{array}{l}\text { Light Brownish } \\
\text { Semi-solid }\end{array}$ \\
\hline 3 & AGL3 & S20:S40 & $900: 100$ & 100 & 100 & 0.5 & 0.18 & $\begin{array}{l}\text { Brown } \\
\text { Transparent } \\
\text { Liquid }\end{array}$ \\
\hline 4 & AGL4 & S20:S60 & $100: 900$ & 100 & 100 & 0.5 & 0.18 & White Semi-solid \\
\hline 5 & AGL5 & S20:S60 & $500: 500$ & 100 & 100 & 0.5 & 0.18 & $\begin{array}{l}\text { White Semi- } \\
\text { Solid }\end{array}$ \\
\hline 6 & AGL6 & S20:S60 & $900: 100$ & 100 & 100 & 0.5 & 0.18 & Brown Liquid \\
\hline 7 & AGL7 & S20:S65 & $100: 900$ & 100 & 100 & 0.5 & 0.18 & $\begin{array}{l}\text { Creamish } \\
\text { Semisolid }\end{array}$ \\
\hline 8 & AGL8 & S20:S65 & $500: 500$ & 100 & 100 & 0.5 & 0.18 & $\begin{array}{l}\text { Pale Yellow } \\
\text { Semisolid }\end{array}$ \\
\hline 9 & AGL9 & S20:S65 & $900: 100$ & 100 & 100 & 0.5 & 0.18 & Brown Liquid \\
\hline 10 & AGL10 & S40:S80 & $100: 900$ & 100 & 100 & 0.5 & 0.18 & Creamish Liquid \\
\hline 11 & AGL11 & S40:S80 & $500: 500$ & 100 & 100 & 0.5 & 0.18 & Creamish Gel \\
\hline 12 & AGL12 & S40:S80 & $900: 100$ & 100 & 100 & 0.5 & 0.18 & $\begin{array}{l}\text { Creamish } \\
\text { Semisolid }\end{array}$ \\
\hline 13 & AGL13 & S60:S80 & $100: 900$ & 100 & 100 & 0.5 & 0.18 & Creamish Liquid \\
\hline 14 & AGL14 & S60:S80 & $500: 500$ & 100 & 100 & 0.5 & 0.18 & Creamish Gel \\
\hline 15 & AGL15 & S60:S80 & $900: 100$ & 100 & 100 & 0.5 & 0.18 & $\begin{array}{l}\text { Yellowish Semi- } \\
\text { solid }\end{array}$ \\
\hline 16 & AGL16 & S65:S80 & $100: 900$ & 100 & 100 & 0.5 & 0.18 & Yellowish Gel \\
\hline 17 & AGL17 & S65:S80 & $500: 500$ & 100 & 100 & 0.5 & 0.18 & Yellowish Gel \\
\hline 18 & AGL18 & S65:S80 & $900: 100$ & 100 & 100 & 0.5 & 0.18 & $\begin{array}{l}\text { Creamish } \\
\text { Semisolid }\end{array}$ \\
\hline
\end{tabular}

* Drug concentration used was $10 \mathrm{mg}$ in each formulation

found to be 11.38 - $25.06 \mu \mathrm{m}$ (without agitation) and $4.14-8.36 \mu \mathrm{m}$ (with agitation).

Vesicle size was found to be smallest in AGL11 formulation $(11.38 \pm 1.70 \mu \mathrm{m})$ due to the presence of Span 85. Increasing hydrophobicity of the surfactant monomer led to a smaller vesicle, a result that is expected since surface energy decreases with increasing hydrophobicity ${ }^{20}$.

For spontaneity studies, the formulations in Table 2 were treated with ethanol, propanol, butanol and isopropanol. It was found that niosomes containing isopropanol and butanol 
Table 2: Encapsulation Efficiency of Various Proniosomal Gel Formulations loaded with Captopril

\begin{tabular}{|c|c|c|c|c|c|}
\hline \multirow{2}{*}{$\begin{array}{l}\text { S. } \\
\text { No }\end{array}$} & \multirow{2}{*}{$\begin{array}{c}\text { Formulation } \\
\text { Code }\end{array}$} & \multicolumn{2}{|c|}{ Vesicle Size \pm SEM $(\mu \mathrm{m})$} & \multirow{2}{*}{$\begin{array}{l}\text { Percent Drug } \\
\text { Loading } \\
( \pm \text { SEM })^{*}\end{array}$} & \multirow{2}{*}{$\begin{array}{c}\text { Rate of } \\
\text { spontaneity } \\
\left(\mathrm{mm}^{3} \times 1000\right)\end{array}$} \\
\hline & & $\begin{array}{l}\text { Without } \\
\text { Agitation }\end{array}$ & With Agitation & & \\
\hline 1 & AGL2 & $25.06 \pm 4.50$ & $8.36 \pm 0.10$ & $78.71( \pm 1.48)$ & $11.19 \pm 0.52$ \\
\hline 2 & AGL5 & $18.09 \pm 1.53$ & $7.59 \pm 0.11$ & $77.76( \pm 1.51)$ & $15.25 \pm 0.28$ \\
\hline 3 & AGL8 & $17.41 \pm 0.94$ & $5.19 \pm 0.23$ & $74.78( \pm 1.72)$ & $14.54 \pm 1.11$ \\
\hline 4 & AGL11 & $11.38 \pm 1.70$ & $6.37 \pm 0.11$ & $73.78( \pm 2.51)$ & $16.58 \pm 0.77$ \\
\hline 5 & AGL14 & $22.40 \pm 1.57$ & $7.75 \pm 0.09$ & $76.77( \pm 1.54)$ & $13.59 \pm 1.17$ \\
\hline 6 & AGL17 & $19.82 \pm 2.16$ & $4.14 \pm 0.18$ & $66.69( \pm 1.57)$ & $7.95 \pm 0.24$ \\
\hline
\end{tabular}

*Mean of three determinations

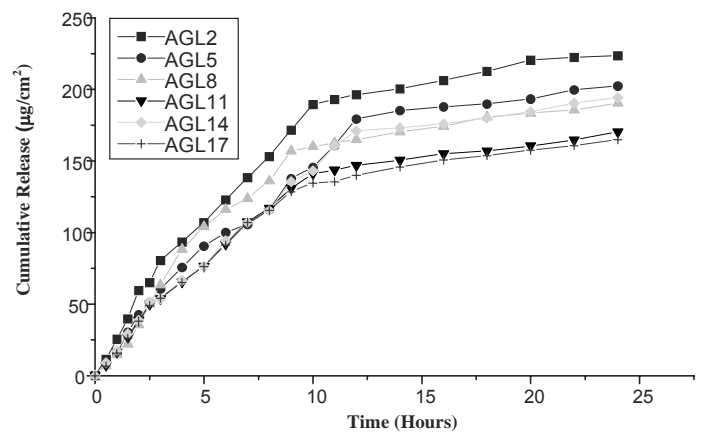

Figure 1: Comparative in-vitro release profile of selected proniosomal gel formulation

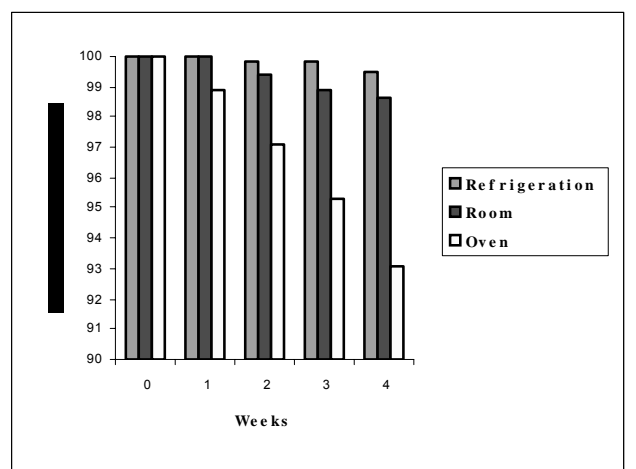

Figure 2: Stability study of AGL2 at different temperatures

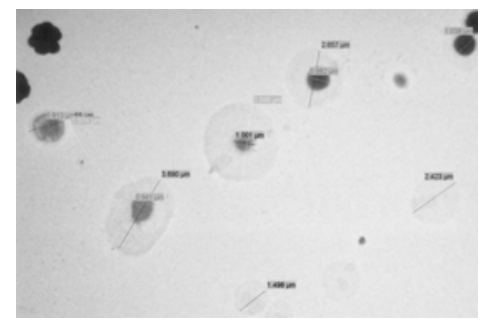

Figure 3: Electron Micrograph of AGL2

were formed more spontaneously than niosomes containing propanol and ethanol perhaps as a result of faster phase separation of isopropanol and butanol due to their lower solubility in water. This result is consistent with those from spontaneity studies of levonorgestrel in proniosomes ${ }^{9}$.

The morphology of niosomes derived from proniosomal gel was studied using Transmission Electron Microcopy. TEM revealed that the 
niosomes formed were spherical and homogenous.

In vitro release studies are often performed to predict how a delivery system might work in an ideal situation as well as give some indications of its in vivo performance since drug release dictates the amount of drug available for absorption. The amount of drug released from different proniosomal gel formulation was found in the order of AGL2 > AGL5 > AGL14 > AGL8 > AGL11 > AGL17 as shown in Fig. 1. It was found that AGL2 showed a controlled release property from 10 to 24 hours. The cumulative release was found to be $189.44 \mu \mathrm{g} / \mathrm{cm}^{2}$ and $223.54 \mu \mathrm{g} / \mathrm{cm}^{2}$ at the $10^{\text {th }}$ and $24^{\text {th }}$ hour, respectively. The release rate was constant from the 10th to the 24th hour. Thus, the formulation exhibited zero order release over this period. This may be attributed to the fact that the molecules of Spans 40 and 60 are in an ordered gel state at the in vitro permeation condition of $25^{\circ} \mathrm{C}$, while the formulation AGL2 showed significantly higher release since Span 85 is in the disordered liquid crystalline state under the same condition ${ }^{21}$. The other formulations AGL5, AGL8, AGL11, AGL14, AGL17 - also showed good controlled release properties. The amount of drug retained within the vesicles under defined conditions ultimately governs the shelf life of the drug. The results showed that proniosomal gel formulation was quite stable at refrigeration and room temperatures as not much leakage of drug was found at these temperatures (see Fig. 2). Percent drug retained at $45^{\circ} \mathrm{C}$ might have decreased due to the melting of the surfactant (m.p.: $48^{\circ} \mathrm{C}$ ) and lipid present in the formulation. Therefore, the proniosomal gel formulations can be stored at either refrigeration or room temperature.

\section{CONCLUSION}

In conclusion, we can state that besides imparting controlled systemic transdermal delivery to captopril, proniosomal gel possesses high entrapment efficiency and utilizes alcohol, which itself can act as a penetration enhancer. The formulation procedure is simple and does not involve lengthy procedures and use of several pharmaceutically excipients.

\section{REFERENCES}

1. Shahiwala A, Misra A. Studies in topical application of niosomally entrapped nimesulide. J Pharm Pharm Sci 2002; 5(3): 220-225.

2. Khandare JN, Madhavi G, Tamhankar BM. Niosomesnovel drug delivery system. East Pharm 1994; 37: 61-64.

3. Fang JY, Yu SY, Wu PC, Huang YB, Tsai YH. In-vitro skin permeation of estradiol from various proniosomes formulation. Int J Pharm 2001; 215: 91-99.

4. Hu C, Rhodes DG. Proniosomes: A Novel Drug Carrier Preparation. Int J Pharm 1999; 185(1): 23-35.

5. Wu PC, Huang YB, Chang JJF, Chang JS, Tsai YH. Evaluation of pharmacokinetics and pharmacodynamics of captopril from transdermal hydrophilic gel in normotensive rabbit and spontaneously hypertensive rats. Int $\mathrm{J}$ Pharm 2000; 209: 87-94.

6. Abubkar O Nur, Zhang JS. Recent progress in sustained/controlled oral delivery of captopril: An overview. Int J Pharm 2000; 194: 139-146.

7. Zhou XH, Li Wan PA. Stability and in-vitro absorption of captopril, enalapril and lisinopril across the rat intestine. Biochem Pharmacol 1994; 47: 1121 1126.

8. Tripathi KD. Essentials of Medical Pharmacology. New Delhi, India, Jaypee Brothers, 2003 pp 449-454.

9. Jain NK, Vora B, Khopade AJ. Proniosome based transdermal delivery of levonorgestrel for effective contraception. J Control Rel 1998; 54: 149-165.

10. Nagarsenker MS, Londhe VY, Nadkarni GD Preparation and evaluation of liposomal formulation of tropicamide for occular delivery. Int $\mathrm{J}$ Pharm 1999; 190: 63-71.

11. Bhatia A, Kumar R, Katare OP. Tamoxifen in topical liposomes: Develoment, characterization and invitro evaluation. J Pharm Pharm Sci 2004; 7(2): 525-259.

12. Joshi YM, Bachman WR, Jani NB. New pharmaceutical composition in the form of beadlets and method. European Patent 1988; EP 288732: A2.

13. Singh J, Robinson $\mathrm{DH}$. Controlled release kinetics of captopril form tableted microcapsules. Drug Dev Ind Pharm 1988; 14(4): 545-560.

14. Leung SHS, Robinson JR. The contribution of anionic polymer structure feature to mucoadhesion. J Contrl Rel 1988; 5: 223-231.

15. Sheth PR, Tossounian J. The hydrodynamically balanced system (HBSTM): A novel drug delivery system for oral use. Dev Ind Pharm. 1984; 10(2): 313-339.

16. Seta Y, Higuchi F, Kawahara Y, Nishimura K, Okada R. Design and preparation of captopril sustained release dosage form and their biopharmaceutical properties. Int J Pharm 1988a; 41: 245-254.

17. Volland C, Woleff M, Lissel T, The influence of terminal gamma sterilization on captopril containing poly CD, L-lactic co Glycolide microsphere. J Control Rel 1994; 31: 298-305.

18. Varghese V, Vitta P, Bakshi V, Agarwal S, Pandey S. Niosomes of primaquine: Effect of sorbitan esters 


\section{Gupta et al}

(spans) on the vesicular physical characterstics. Indian Drugs 2004; 41(2): 101-103.

19. De Gier J, Mandersloot JG, Van Deenen LLM. Lipid composition and permeability of liposomes. Biochem Biophys Acta 1968; 150: 666-675.

20. Wan LSC, Lee PFS. Studies on surface film of sorbitan esters at the air/water interface. Can J Pharm 1974a; 9: 82-85.

21. Yoshioka T, Steonberg B, Florence AT. Preparation and properties of vesicles (niosomes) of sorbitan monoesters (span 20, 40, 60 and 80) and a sorbitan triester (span 85). Int J Pharm1994; 105: 1-6. 